\section{NÉHÁNY GONDOLAT A SÉRELEMDÍJ IRÁNTI IGÉNY JOGUTÓDLÁSA KAPCSÁN}

Dr. Görög Márta PhD (egyetemi tanár, SZTE ÁJTK Civilisztikai Tudományok Intézete, intézetvezetö)

\section{ÖSSZEFOGLALÓ}

A személyiségi jogok megsértése esetén az elszenvedett immateriális hátrányok kompenzációjaként szolgáló magánjogi jogkövetkezmény, a nem vagyoni kártérítés, a 2013. évi V. törvény (Ptk.) szerinti sérelemdíj jogutódlása aktuális és élő kérdése a jogalkalmazási gyakorlatnak. Az uralkodó és következetes jogalkalmazási gyakorlat, valamint jogelmélet nem támogatja az igény átszállását, valamint öröklését, kivételesen a sérelmet szenvedett által peres úton már érvényesített igény jogutódlását ismeri el. Az érintett által a biztosítótársasággal szemben érvényesített igény esetén nem biztosítja az igénynek az örökösökre való átszállását. Az európai magánjogi modelleket, különösen az osztrák és német modellt, valamint a perbeli jogutódlás mögött meghúzódó jogi indokot tekintve úgy véljük, aktuális felvetni a peren kívül már érvényesített igény jogutódlását.

\section{SUMMARY}

Compensation of non-material damages in case of violation of personality rights as the legal consequence of the private law and as the succession of restitution according to the Hungarian Civil Code of 2013 is a current and living issue. The idea of transfer and inheritance of claim is not supported either by the prevailing and consistent application of case-law or by the theory of law. However, succession of claim which has already been enforced in a court procedure by the injured party is accepted exceptionally. Transfer of claim to heirs is not provided if the claim has enforced against the insurance company by the person affected. Considering the European private-law models, particularly the Austrian and German models, and the legal reasons behind the succession in litigation, in our point of view, it is current to suggest the succession of claim which has already been enforced out of court.

Kulcsszavak: sérelemdíj, személyiségi jog, jogutódlás

Key words: non-material damages, personality rights, transfer of claim

JEL: K10

DOI: $10.18530 /$ BK.2018.1.14

http://dx.doi.org/1018530/BK.2018.1.14
Jelen tanulmányban a Debreceni Törvényszék egyik, Barta Judit tanszékvezető által figyelmembe ajánlott ítélete alapján a biztosítóval szemben már érvényesített, ugyanakkor még ki nem fizetett, peresített igényérvényesítés stádiumába el nem jutott nem vagyoni kártérítés iránti igény anyagi jogi és ezáltal eljárásbeli jogutódlásának újra felvetődött kérdéskörét járom körül. A felvetett kérdés lényege valójában az, hogy az érintett személy halála után ki és milyen jogalapon nyugodva érvényesíthet sérelemdíj iránti igényt, illetve egyáltalán a felperesi legitimáció adottságként kezelhetö-e ezen esetekben. A tanulmány kitér egyes külföldi jogi megoldásokra, különösen az osztrák és német mintára, annak szándékával, hogy felmérje, milyen megfontolások alakultak ki a feltett kérdések kapcsán.

A személyiségi jogok sérelme esetén megnyíló immateriális igények jogutódlásának problematikája sokszínű, mely sokszínűség a személyiségi jog többrétűségéhez köthető. A felvetett téma a személyiségi jogok post mortem védelmének körébe vezet el bennünket, ahol alapvetően két tényállást szükséges vizsgálni: így azt az iniuriát, amely az érintett halála után következik be, illetve azt a tényállást, ahol a jogsértő magatartás az érintett halálával jár. Két síkon kell vizsgálni a magánjogi értékelést, miszerint ki és milyen jogalapon nyugodva érvényesíthet sérelemdíj iránti igényt.

Az elhunyt személyiségi értékeit sértő post mortem magatartások a kegyeleti jogosult ${ }^{1}$ önálló személyiségi jogát sértik. Az elhunyt személyiségi értékei transzformálódnak a kegyeleti jogosult személyiségi jogává. Emberi méltóság alapú személyiségi rendszerünk ekként tudja feloldani azt az ellentmondást, amely a személyiségi jog halál utáni védelme és a rendelkezési jog gyakorlásának kizárása között feszültt. ${ }^{2} \mathrm{~A}$ kegyeleti jog alapvetően kielégítően rendezi az elhunyt halála után bekövetkezett jogsérelmek miatti igényérvényesítést. Az érintett post mortem személyiségi értékeinek ekkénti védelme nem mond ellent a személyiségi jogok személyes érvényesítését megkövetelő premisszájának. A kegyelet - az elhunyt emlékének védelme, tiszteletben tartása - sajátos természetű érzés, emberi érték, a személyiség sajátos megnyilvánulása, a személyiség része, amely a társadalmi fejlődés következtében jogi színezetet, tényleges jogi tartalmat is nyert. A kegyeleti jog abszolút szerkezetű jogként az elhunyt emlékének magánjogi eszközök útján megvalósuló védelme mellett magában foglalja a halott eltemettetésének jogosultságát és az ahhoz kapcsolódó „mellékjogosultságokat”.

A halálos kimenetelü testi sérelmek esetén egymástól elkülönítve értékelendő a kegyeleti jogosult igényérvényesítésének, valamint a sérelemdíj jogutódlásának, örökölhetőségének kérdésköre. A halált eredményező személyiségi jogsértés esetén a hozzátartozók saját jogon élhetnek sérelemdíj iránti igénnyel. A sérelemdij jogutódlása, örökölhetősége alapvetően ugyanezen alanyi kör kapcsán bír relevanciával. Amennyiben a sérelmet szenvedett keresettel élt, és annak eredményessége esetére a bíróság olyan jogkövetkezményt, így sérelemdíjat állapított meg, amely az őt ért hátrányokat pénzzel reparálja, úgy az elhunyt számára megítélt, de részére meg nem fizetett sérelemdíj a hagyatékához tartozik, ${ }^{4}$ az örökösét illeti. 
A sérelemdíj iránti perekben a felperesi oldalt érintően a Ptk. kimondja, hogy a személyiségi jogokat csak személyesen lehet érvényesíteni. ${ }^{5} \mathrm{Ez}$ az anyagi jogi jogutódlás kizártságát vonja maga után. A judikatúra azonban megengedi az örökösök utóbbi perbelépését akkor, ha a személyiségi jogában megsértett személy sérelemdíj megfizetésére irányuló igényét per útján érvényesítette, keresetlevelében az általa érvényesíteni kívánt jogot az annak alapjául szolgáló tények előadásával megjelölte, valamint határozott kereseti kérelmet is előterjesztett. Ezzel ugyanis a személyiségi jogról való rendelkezés az anyagi jogi jogosult részéről megtörtént. A legfőbb bírói fórum több eseti döntésében mondta ki, hogy a károsult által már megindított per esetén az örökös a perbe jogutódként belépve érvényesítheti a nem vagyoni kártérítés iránti követelését. ${ }^{6} \mathrm{~A}$ Pp. általános szabálya ${ }^{7}$ a sérelemdíj kapcsán is helytálló e vonatkozásban. A bevezetésben jelölt ítélet - még az 1959-es Ptk.-n nyugvó nem vagyoni kártérítés anyagi és eljárásjogi jogutódlásával kapcsolatban - utalt a fenti megfontoláson nyugvó uralkodó és irányadónak tekinthető bírósági jogalkalmazási gyakorlatra, amely „kivételesen és kizárólag a már peresített igényérvényesítés stádiumába juttatott nem vagyoni kártérítési követelések tekintetében ismeri el a vagyoni jogutódlás, egyben az anyagi jogi jogutódlás, és erre figyelemmel az eljárásbeli jogutódlás lehetőségét." ${ }^{8} \mathrm{Az}$ ítéleti tényállás alapján a károsult egy közlekedési baleset során elszenvedett immateriális hátrányai okán terjesztette elő kárigényét alperesi biztosítótársaságnál, ugyanakkor egy újabb közlekedési balesetben bekövetkezett haláláig nem kezdeményezett a nem vagyoni kártérítési követelése iránt peres eljárást. A bíróság ítéletében megállapította, hogy örököse a követelés tekintetében nem minősül jogutódnak, ezért a követelést alperes alappal nem érvényesítheti. Ha továbbgondoljuk, ez a felfogás azzal a következménnyel járhat, hogy amennyiben a károkozó magatartás okán halál bekövetkezte fenyeget, a jelenlegi szabályozásból adódóan versenyfutás veheti kezdetét a „még hátralévő idővel” szemben. Olyan abszurd, ámde életszerű esetek is előfordulhatnak, ahol a károsult halálos ágyán ad ügyvédi meghatalmazást, és az ügyvéd a versenyfutás „hajrájának” utolsó perceiben igyekszik érkeztetni az általa megszerkesztett keresetlevelet az illetékes bíróságon. A keresetlevél benyújtásának anyagi jogi következménye lesz a sérelemdíj iránti igény vonatkozásában bekövetkező perbeli jogutódlás.

Boytha Györgynek a sérelemdíj témájában elsők között megjelentetett tanulmánya már jelezte, hogy a sérelemdíj iránti igény nem száll át halál esetén másra. ${ }^{9}$

Úgy vélem, a fenti esetben azzal, hogy az érintett a nem vagyoni kártérítés iránti igényét a biztosítótársasággal szemben érvényesítette, részéről a személyiségi jogról való rendelkezés megvalósult. Számtalan indoka lehet ugyanis annak, hogy az érintett korábban miért nem érvényesítette igényét a bíróság előtt. Szentgyörgyi Rezső egy 1980-as tanulmányában ezek közé sorolta azt, ha az érintettek a peren kívüli rendezés reményében halasztják el a perindítást, a károsult a perindítást akadályozó testi sértést szenvedett, vagy miután a legtöbb esetben a jogkövetkezményért a biztosítótársaság - 1980-ban az Állami Biztosító - áll helyt, ezért a károkozó fizetésképtelenségétől való félelem a mielőbbi perindításra nem ösztönöz. ${ }^{10}$
Az érintett személy halálával megszünik a védett jogtárgy, az a jogalany, akinek a személyét érte a sérelem, és akinek oldalán kell, hogy jelentkezzék a sérelemdíj kompenzációs és prevenciós funkciója. Azonban ha ezen utóbbi funkciót tekintjük, úgy az átszállást támogató jogalkalmazói gyakorlat alkalmas lehet az eszmei kárt eredményező magatartásokkal szembeni preventív funkció betöltésére. Zoltán Ödön - bár nem ezen problémakört érintő - nem vagyoni kártérítés melletti érve e helyen is időtálló, hiszen a szabad átszállásnak preventív szerepe lehet, „a jövőbeni jogsértésekkel szemben visszatartó hatást fejthet ki amellett, hogy kifejezésre juttatja a társadalom [...] helytelenítő értékítéletét."11

A külföldi modellek közül különösen azokat érdemes megvizsgálni, melyek a magyarhoz hasonló emberi méltóság alapú személyiségvédelmi rezsimmel bírnak.

A külföldi magánjogi megoldásokat tekintve Írországban, ${ }^{12}$ Finnországban ${ }^{13}$ és Svédországban ${ }^{14}$ az igény jogutódlása megengedett. A görög jog a fájdalomdíjigény jogutódlásának feltételéül szabja az Art. 933 ZGB alapján, hogy a kötelezett a sérelmet szenvedett fél igényét még annak életében elismerje, vagy a sérelmet szenvedett fél bíróság előtt érvényesítse igényét. Svájcban ma már elismerten a "Genugtuungsanspruch” az Art 47 OR szerint generálisan átruházható és aktívan öröklődik, akkor is, ha a jogosult az igény érvényesítésére vonatkozó akaratát halála előtt nem nyilvánította ki. ${ }^{15}$ Dániában a személyiségi jogok megsértése miatt támasztható igények csak akkor örökíthetőek át, ha az elismerésre vagy kereset útján érvényesítésre került. ${ }^{16}$

A külföldi modellek közül különösen azokat érdemes megvizsgálni, melyek a magyarhoz hasonló emberi méltóság alapú személyiségvédelmi rezsimmel bírnak, így az osztrák és a német modell nyújthat olyan tapasztalatokat, melyek a magyar jog szempontjából megfontolást érdemelhetnek.

Az osztrák joggyakorlat és jogelmélet művelőinek az alapvető „problémát” a fájdalomdíjra irányadó alapvető jogszabályhely egyetlen kifejezése, az „auf Verlangen” jelentette. Az $₫ 1325$ ABGB alapján az, „aki más személynek testi sérelmet okozott, [...] az köteles a sérelmet szenvedőnek annak igénye szerint (auf Verlangen) a felmerült körülményeknek megfelelő mértékű fájdalomdíjat fizetni.” A jogutódlás kérdése mellett már a XIX. sz. elméleti jogászai sem tudtak szó nélkül elmenni. Unger már másfél évszázaddal ezelőtt a megengedhetőség előfeltételeit vizsgálta. ${ }^{17} \mathrm{~A}$ jogelméletben eluralkodott vitát lezárva az OGH 1913-ban a döntvénytárban 204-es szám alatt bevezetett döntésében kimondta, hogy a fájdalomdíjigény átörökíthető és átruházható, amennyiben az igény a sérült életében szerződéssel elismerésre került, vagy a jogosult a keresetet megindította. ${ }^{18} \mathrm{Az}$ OGH vitát elsimítani igyekvő törekvése következmény nélkül maradt. Később 1968-ban korszerűsítették a fájdalomdíj intézményét. Az „auf Verlangen” követelménye kiüresedett azáltal, hogy 
az EKHG novellájának 12. \$-a értelmében a fájdalomdíjra irányuló igény már a sérüléskor létrejön, és örökölhető. Majd további enyhítést eszközölt ezen a szigorú értelmű szabályozáson 1976-ban az OGH. ${ }^{19}$ Az osztrák jogalkotó az 1992. március 1. napján hatályba lépett EO-Nov 1991 BGBl 628-cal a fájdalomdíjigény zálogosíthatóságának a szerződéses elismeréstől, illetve bírósági igény érvényesítésétől való eddigi függőségét megszüntette. További öt évnek kellett eltelnie, míg az OGH az örökölhetőségnek új konzekvenciáit szabta meg: az E 30.9.1996, 6 Ob 2068/96 b döntésében arra az álláspontra helyezkedett, hogy a $\$ 1325$ ABGB-ben szabályozott ,auf Verlangen” kifejezés az 1991-es EO-Novella óta semmilyen egyedülálló jelentéssel nem bír. A fájdalomdíjigény érvényesítése független a sérült igényérvényesítésétől, a törvényileg szabályozott és védett fájdalomdíjigény örökölhetö. ${ }^{20}$ Ugyanakkor a sérült gyors vagy közeli halála - a fájdalom rövid ideje miatt - a mérték csökkentését eredményezi.

A német jogalkalmazási gyakorlat kezdetben kétkedéssel fogadta a szabad átszállás gondolatát. A BGB nem vagyoni károkról rendelkező szakaszhelye ${ }^{21}$ szerint csak törvényben meghatározott esetekben lehet a nem vagyoni károk elszenvedése esetén pénzbeli kiegyenlítést eszközölni. Az igény átruházhatósága, örökölhetősége kérdésében, mint egyik specifikus törvényi tényállásról, a fájdalomdíjról rendelkező szakaszhelye adott támpontot. Az elméleti és gyakorlati jogászok - hasonlatosan a magyar jogművelőkhöz - a személyiségi jog, illetve nem vagyoni károk igen nagyfokú személyi jellegét tekintették kiindulási alapnak, és annak érvényesítését az érintett személy akaratától tették függővé. A BGB a $\$ 847$ I S. 2-ben akként rendelkezett, hogy a fájdalomdíjigény csak akkor örökíthető és ruházható át, ha azt szerződéssel elismerték, vagy perfüggőség állt fenn. A 15. Deutscher Verkehrgerichtstag 1977 azt az ajánlást intézte a jogalkotó felé, hogy a $\$ 847$ BGB szerinti fájdalomdíjigény váljék szabadon átörökíthetővé a közvetlenül sérelmet szenvedett fél legközelebbi hozzátartozói vonatkozásában. A német jogalkotó az 1990. július 7. napjával hatályba lépett BGB Novellával törölte a BGB $\$ 847$ sérelmezett rendelkezését. A valójában eléggé tiszta jogi helyzet ellenére a BGH egy, az 1994. december 6. napjáról származó ítéletében újból foglalkozott a fájdalomdíjigény örökléséhez és átruházásához szükséges akaratnyilatkozattal mint előfeltétellel, és világossá tette, hogy az újabb jog szerint egy ilyen előfeltétel többé már nem szükséges. ${ }^{22}$ Perbeli esetben a felperes - elhunyt fiának, A.-nak az örököseként az - alperessel szemben fájdalomdíj iránti igénnyel lépett fel. A. 1992. június 17. napján az alperes által okozott közlekedési balesetben súlyosan megsérült, mely sérülések következtében 1992. augusztus 7. napján elhalálozott. A baleset és a halál bekövetkezte közötti idő túlnyomó részében A. nem volt eszméleténél. Ítéletében a bíróság megállapította, hogy a $\$ 847$ I 2 BGB módosítása okán a felperes elhunyt fia örököseként minden további elöfeltételek nélkül szabadon érvényesítheti a fiától megörökölt fájdalomdíjigényt. „[...] A fájdalomdíjigény felperesre öröklés útján háramlik akkor is, ha a sérült ezt az igényét életében nem nyilvánította ki, függetlenül attól, hogy ezt egészségi okokból megtehette vagy sem."23

Az újabb szabályozás mentén a rövidebb vagy igen rövid túlélési idő esetére megítélendő fájdalomdíj összegszerüségének kérdésköre merült fel. Az a gyakorlat uralkodott, hogy éppen az időbeli körülmények miatt szabály szerint csak azok a fájdalomdijigények öröklődtek, melyek esetében a fájdalom időtartama legalább két-három napig tartott, mivel azelőtt nem volt lehetőség ügyvéddel, biztosítóval való kapcsolatfelvételre. Az új jogi helyzetben egyre gyakrabban merült fel kérdésként, hogy vajon akkor, amikor a sérült személy a balesetet csupán néhány perccel élte túl, fájdalomdíjigény (és milyen mértékü) egyáltalán keletkezik-e. Az LG Heilbronn hozott e kérdéskörhöz kapcsolódóan először ítéletet. ${ }^{24}$ Az ítéleti tényállás szerint a 17 éves „,jogelődöt” embertelen módon összesen tizenegy késszúrással meggyilkolta a „barátja”. A bíróság megkísérelte a fájdalomdíj kiegyenlítési és elégtételi funkciójának összekapcsolását, amikor is kimondta: „Az egyébként szokásos elégtételi funkció jelen esetben nem nyer alkalmazást, mivel az elhunyt néhány percen belül életét vesztette. Mindemellett mindaz, amit megélt, elszenvedett, a kompenzáció fényében elégtételre tart számot."

\section{Záró gondolatok}

A magunk részéről a személyiségvédelemnek azt a felfogását valljuk, amely az érintett halála után is ugyanolyan magánjogi védelemben részesíti az elhunyt személyiségi értékeit, mint életében. Ennek okán a kegyeleti jog és ezáltal a kegyeleti jogosultak kiterjesztő értelmezését támogatjuk. Ezen felfogás egyik következményeként a sérelemdíj iránti igény átruházhatósága és örökölhetősége mellett foglalunk állást, mely felfogás nem idegen az emberi méltóság alapú személyiségvédelmi magánjogi felfogásoktól, hiszen a fentebb megjelölt osztrák és különösen német modell ezen premisszán nyugodva biztosítja a szabad jogutódlást. Ahogy azt a megnyílt német jogalkalmazási gyakorlat is mutatta, a rövid túlélési idejű személyiségi jogsértések esetén érvényesíthető, funkcióanalízisen nyugvó fájdalomdíjigények összegszerűsége vetett fel koherenciazavarokat a judikatúrában. A sérelemdíj mint generalis preventio, mint az elszenvedett immateriális sérelmek pénzbeli elégtétellel történő egyösszegű kompenzációja értékelendő e vonatkozásban. A kérdés csupán az, mit és miként tanulhatunk e külföldi modellekből, és adaptálhatóak-e azok a magyar magánjogba.

A szabad átszállás elfogadásáig is azt a felfogást támogatjuk, amely a sérelemdíj iránti igény jogutódlását és örökölhetőségét elfogadja azokban az esetekben, amikor az érintett igényét a biztosítótársasággal, a jogsértővel szemben érvényesítette, illetve különösen akkor, amikor a jogsértés okozója elismerte az érintett sérelemdíj iránti igényét figyelemmel arra, hogy a jogosult ezen esetekben meghatározta érvényesíteni kívánt igényét, rendelkezett a személyiségi jogról. 


\section{HIVATKOZÁSOK}

${ }^{1}$ Ptk 2:50.\$ (1) bek.

${ }^{2}$ Petrik Ferenc: A személyiség jogi védelme, Közgazdasági és Jogi Könyvkiadó, Budapest, 1992. 211.; Törö Károly: Kegyeleti

jog, Jogtudományi Közlöny, 1972. évf. áprilisi szám, 165.

${ }^{4}$ Leg. Bír. Pfv. IV. 20. 705/1996. sz.

${ }^{5}$ Ptk. 2:54.\$ (1) bek.

${ }^{6} \mathrm{BH} 1996.639 . ; \mathrm{BH}$ 1997.435.; BH 1999.363.

72016. évi CXXX. törvény 47.\$(1) bek.

${ }^{8}$ EBD 2014.P.2.=Debreceni Törvényszék 4.Pf.21.030/2012/7

'Boytha György: A személyiségi jogok megsértésének vagyoni szankcionálása, Polgári Jogi Kodifikáció, 2003. V. évf. 1. szám, 5.

${ }^{10}$ Szentgyörgyi Rezső: Gondolatok a nem vagyoni károk téritéséről, Biztosítási Szemle 1980. november-decemberi szám, 274.

"Zoltán Ödön: A nem vagyoni kár megtéritéséről, Magyar Jog, 1991. évf. 9. szám, 416.

${ }^{12} \sec .7$ [2] Civil Liability Act 196

${ }^{13} 7$ Kap., $3 \$$ SKL
${ }^{14} 5$ Kap., $2 \$$ SKL

${ }^{145}$ Kap., 2 \$ SKL

Schnyder in: Honsel/Vogt/Wiegand: Kommentar zum Schweizerischen Privatrecht, VVG, Basel, Genf, München, 2001., OR I, 347 f; illetve 274. lábjegyzeténél idézett szerzők.

${ }^{165} 18$ Abs. 2 EAL

${ }^{17}$ Unger, Joseph: System des österreichischen allgemeinen Privatrechts I., Breitkopf und Härtel, Leipzig, 1856., 571. FN 15; II., 1859., 535. oldal FN 10 .

AmtSlg $1503=$ GIUNF 6485

${ }^{20}$ Uttó György: A kártérítési jog reformja az Európai Unió egy tagállamában, Ausztriában; Bírák Lapja, 2002/2. 97; ZVR $1996 / 126$

${ }^{22}$ BGH 6. 12.94 - VI ZR 80/94=NJW 95,783

${ }^{23}$ BGH, Urteil vom 06.12.1994 - VI ZR 80/94 (Oldenburg)

${ }^{24}$ LG Heilbronn, 16. 11. $93-2$ O 2499/92.

\section{IRODALOMJEGYZÉK}

Boytha György: A személyiségi jogok megsértésének vagyoni szankcionálása, Polgári Jogi Kodifikáció, 2003. V. évf. 1. szám, pp. 3-6.
Honsell, Heinrich/Vogt, Nedim Peter/Wiegand, Wolfgang: Kommentar zum Schweizerischen Privatrecht VVG, Basel, Genf, München, 2001

Petrik Ferenc: A személyiség jogi védelme, Közgazdasági és Jogi Könyvkiadó, Budapest, 1992.

Szentgyörgyi Rezső: Gondolatok a nem vagyoni károk térítéséról, Biztositási Szemle 1980. november-decemberi szám

Toró Karoly: Kegyeleti jog, Jogtudomanyi Kozlöny, 1972. evf. áprilisis szám,

Uttó György: A kártérítési jog reformja az Európai Unió egy tagállamában, Ausztriában; Bírák Lapja, 2002/2.

Zoltán Ödön: A nem vagyoni kár megtérítéséről, Magyar Jog, 1991. évf. 9. szán 